\title{
(2) OPEN ACCESS \\ Atypical localisation of pleomorphic adenoma issue from heterotopic salivary tissue in the supraclavicular region: diagnosis and management
}

\author{
Bassel Hallak, ${ }^{1}$ Mohamed Ehab Kamel, ${ }^{2}$ Salim Bouayed, ${ }^{1}$ Stephane Yerly ${ }^{3}$
}

${ }^{1}$ Otorhinolaryngology, Sion Hospital Valais Romand Hospital Center, Sion, Valais, Switzerland ${ }^{2}$ Radiology, Hôpital de Sion Centre Hospitalier du Valais Romand, Sion, Valais, Switzerland

${ }^{3}$ Pathology, Sion Hospital Valais Romand Hospital Center, Sion, Valais, Switzerland

\section{Correspondence to} Dr Bassel Hallak; bassel2004@hotmail.com

Accepted 8 October 2020

Check for updates

(c) BMJ Publishing Group Limited 2020. Re-use permitted under CC BY-NC. No commercial re-use. See rights and permissions. Published by BMJ.

To cite: Hallak B, Kamel ME, Bouayed $\mathrm{S}$, et al. BMJ Case Rep 2020;13:e237583. doi:10.1136/bcr-2020237583

\section{SUMMARY}

Heterotopic salivary tissue (HST) is a normal salivary tissue located outsides the major and minor salivary glands. Multiple sites of localisation of heterotopias have been described, the occurrence of HST in the neck is rare and it may have several clinical manifestation. We report the case of 72-year-old Caucasian man presenting a suspect mass on the left-sided supraclavicular region. He is known for melanoma of the right elbow, surgically treated 11 years ago. The final diagnosis of pleomorphic adenoma of HST was retained. Methods of diagnosis and management are documented. Neoplasms arising from HST are uncommon with approximately $80 \%$ of benign tumours. Warthin's tumour is the most frequent. The localisation of these neoplasms in the lower neck is very rare and often causes a diagnostic pitfall. Histological analysis provides certainty of diagnosis, defines management and follow-up.

\section{BACKGROUND}

Heterotopic salivary gland tissue (HSGT) is characteristic by an abnormal anatomic presence of salivary tissue at localisation other than known major and minor salivary glands. These heterotopias localisation include; lymph nodes, thyroglossal duct cyst, external auditory canal, hypophysis, mandible, mastoid bone, middle ear, tongue, thyroid and parathyroid glands, upper and lower neck regions. ${ }^{1}$ The occurrence of heterotopic salivary tissue (HST) in the neck is rare and may have variant clinical manifestation, such as, cyst, mass or draining sinus. ${ }^{2}$

Different hypothesis to explain the embryogenesis of this kind of heterotopic tissue have been proposed by Willis in $1968^{3}$; an abnormal persistence and development of vestigial structures; dislocation of a portion of a definitive organ rudiment during mass movement and development and abnormal differentiation of the local tissues.

Neoplasms developing from HSGT in the neck are rare entities. Hildebrand made the first description in the literature of a case of heterotopic Warthin's tumour in the neck in $1895 .^{3}$ In 1910 , Singer $e t a l^{4}$ described a case of papillary cystadenoma occurring within a cervical lymph node.

Histologically, tumours originating from HSGT are similar to those lesions arising in normally situated salivary tissue. ${ }^{5}$ The majority of these tumours are benign with Warthin's tumour remains the most frequent, but other benign and malignant tumours have been documented.
We report a case of pleomorphic adenoma arising from HSGT in the supraclavicular region, mimicking metastatic lymph node in a patient with a history of melanoma. Clinical manifestation, radiological findings, histological characteristics, management and follow-up are documented.

\section{CASE PRESENTATION}

A 72-year-old Caucasian man was referred to the department of otorhinolaryngology for investigations and management of left-sided supraclavicular mass. He was in good general health and his medical background showed a history of melanoma type superficial spreading melanoma in the right elbow, initially staged; Clark III, Breslow 0.77, treated surgically 11 years ago; he was followed-up by his dermatologist with no evidence of local recurrence or distant metastasis.

He presented a supraclavicular mass on the left side, appeared since 4 months with a progressive evolution. An initial evaluation of this mass was made by his dermatologist with a fine needle aspiration biopsy. Thin Prep processed sample did not showed any melanoma cells but a moderately cellular specimen containing slightly atypical epithelial-type cell. Cohesive sheet of cells with increased nucleocytoplasmic ratio were intermixed with plasmocytoid discohesive cells, rare oncocyte cells were also present (figure 1A-C).

The otorhinolaryngology examination showed a left-sided supraclavicular solid mass, measured approximately $2 \times 3 \mathrm{~cm}$, subcutaneous, mobile and painless on palpation. There was no evidence of other cervical mass. The patient had no symptoms, such as sore throat, dysphagia, dyspnoea or dysphonia. The clinical examination of the oral cavity showed discreet asymmetry in favour of the right palatine tonsil with no evidence of any exophytic or ulcerated lesion. The rest of the clinical examination of the hypopharynx and larynx did not showed any other pathological signs or suspicion lesion.

Taking into considerations the patient's history of melanoma and the suspicious clinical and cytological criteria of the left-sided supraclavicular mass, a total body radiological evaluation by positron emission tomography (PET)-CT was performed and showed a metabolic hyperactivity of the supraclavicular mass, on the left side (maximum Standardized Uptake Value (SUV) at 3.2). Asymmetric metabolic hyperactivity on both 


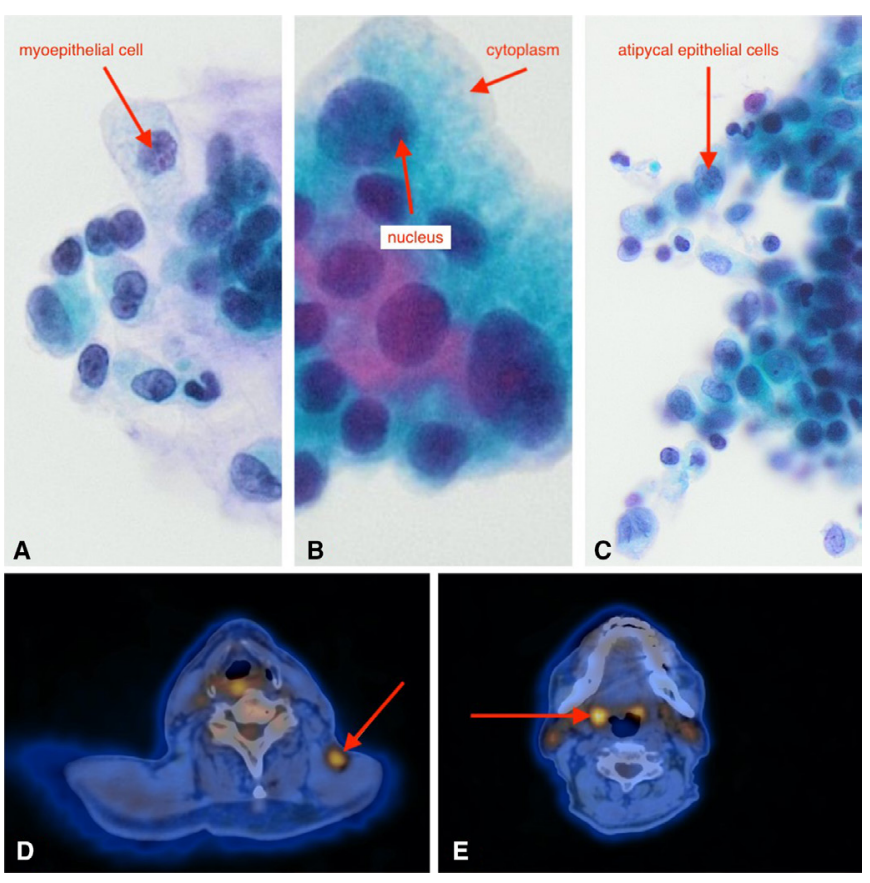

Figure 1 (A) Cytological slide shows a discohesive of myoepithelial cells. (B) Cytological slide shows cluster of oncocyte cells. (C) Cytological slide shows cluster of atypical epithelial cells. (D) PET-CT axial view shows a metabolic hyperactivity of the supraclavicular mass on the left side. (E) PET-CT axial view shows a metabolic hyperactivity on both palatine tonsils on favour the right side.

palatine tonsils, on favour the right side (maximum SUV at 5.9) (figure 1D,E).

In view of the absence of clear and precise diagnosis regarding the supraclavicular mass on the left side as well as the suspicious clinical and radiological criteria of both palatine tonsils, the decision to perform a surgical resection of the left-sided cervical mass in combination with bilateral tonsillectomy was made after discussion with the patient. The surgery was performed under general anaesthesia. There was neither intra-nor postoperative complications.

The patient was monitored for 5 days after the surgery; the cervical drain was removed 2 days later without evidence of local complications. There was no problems of scaring or any complications on both palatine tonsils cavities. Oral feeding has been adapted according to the clinical progresses and patient's ability to eat. The patient was discharged 5 days after the surgery and was followed-up ambulatory.

Histological analysis of both tonsils showed a lypmhoepithelial proliferation without any anomalies or signs of malignancy. The macroscopic appearance of the supraclavicular mass consisted of an elastic nodule, measured $3 \times 1,8 \times 1 \mathrm{~cm}$ with a shiny myxoid cut surface (figure $2 \mathrm{~A}$ ). The whole-mount slide of the nodule showed a well-circumscribed intranodal lesion consisting of variable sized cystic structure intermixed with basophilic epithelial sheet and acidophilic stromal component (figure 2B). The microscopic analysis revealed an intranodal proliferation with a biphasic growth pattern of epithelial/myoepithelial cells and chondromyxoid stroma. Compact sheet of epithelial cells focally forming ductal structure were associated with less cohesive ovoid myoepithelial cells interspersed in a chondomyxoid stroma (figure 2C). A more oncocyte type of epithelium layered some of the ductal structure (figure 2D), the mitotic index MIB was at $14 \%$. In immunostaining study, this proliferation was
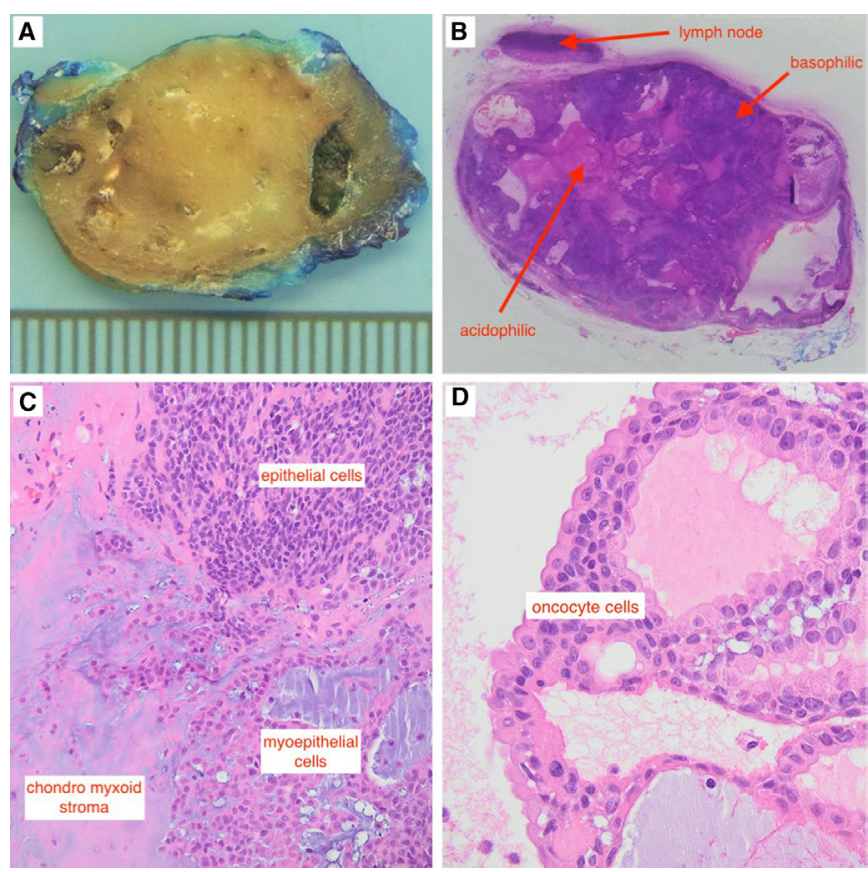

Figure 2 (A) Macroscopic slide of the supraclavicular mass shows an elastic nodule. (B) Macroscopic slide of the supraclavicular mass shows a lymph node with. Basophilic and acidophilic cells. (C) Microscopic slide of the supraclavicular mass shows grouping of epithelial and myoepithelial cells with chondromyxoid stroma. (D) Microscopic slide of the supraclavicular mass cluster of oncocyte cells.

positive for the following markers: SOX10, P63, GFAP and keratin 5/6 with partial expression for Gata 3 and cytokeratin 7. There was no expression for CEA, Actin, PAX8, chromogranin, synaptophysin, CK20, PSA, HMB45, TTF1 and CDX2. These microscopic and immunostaining findings were compatible with benign salivary tissue proliferation type pleomorphic adenoma into a lymph node.

This diagnosis makes the hypothesis of a tumour developed from HST within a cervical lymph node as the most likely to explain this clinical situation.

Due to the benign nature of the supraclavicular mass, no further investigations or procedures were performed. Cervical ultrasonography of control 3 months after the surgery did not revealed recurrence of the tumour. The follow-up is still ongoing.

\section{OUTCOME AND FOLLOW-UP}

Patient's background shows a history of melanoma of the right elbow, 11 years ago treated surgically with no evidence of local recurrence or distant metastasis.

Recent appearance of supraclavicular mass on the left side with progressive evolution.

Clinical, radiological and cytological findings of the mass were highly suspect for metastasis of already known melanoma.

Histological analysis of the excised mass confirmed the diagnosis of benign pleomorphic adenoma issue from HSGT.

Ultrasonography 3 months after the surgery did not showed any local recurrence or appearance of other cervical mass. Close follow-up is still ongoing.

\section{DISCUSSION}

Salivary tissue of the head and neck region is normally present in the major and minor salivary glands. The presence of this tissue in the accessory salivary glands (immediate anterior periparotid 
region) is often occur in association with branchial cleft anomalies. Salivary tissue present outside the major, minor and accessory salivary glands with no evidence of branchial cleft anomalies defined as HSGT. ${ }^{6}$

At the head and neck level, HSGT is more likely occur in the upper neck, different hypothesis explained the appearance of HST in the lower neck, such as defective of closure of the precervical His sinus according to Youngs and Scofield. ${ }^{7}$ Downward migration of aberrant glandular tissue of pharyngeal pouch either with the thyroid and parathyroid gland or to the area of the cervical sinus as proposed by Jernstrom and Prietto. ${ }^{8}$ Himalstein ${ }^{9}$ suggested the persistent of 10th nerve placodal duct, as the ectodermal source of HSGT.

HSGT could be affected by the same disorders of those of the major and minor salivary glands, including inflammatory, infectious, as well as neoplastic diseases. About $80 \%$ of neoplasms arising from HST are benign tumours with pleomorphic adenoma to being the second most commonly reported after Warthin's tumour. In a meta-analysis published in 1999 by Ferlito $e^{2} \mathrm{al}^{3}$ founded that heterotopic salivary neoplasms of the head and neck were mainly in adults, with a few paediatric cases. Cervical neoplasms arising from HST have been found mainly in the upper neck (periparotid, jugulodigastric region). ${ }^{2}$

In a clinical study of 24 patients who diagnosed for cervical neoplasms arising from HST reported by Daniel and McGuirt ${ }^{10}$; Warthin's tumour was the most common benign neoplasm with about an equal localisation in the periparotid region and the upper neck.

Pleomorphic adenoma is usually associated with good prognosis, but could carries the risk of local recurrence or even malignant transformation in 3\%-15\% of cases; according to the literature only one case of carcinoma ex pleomorphic adenoma originating from HSGT was reported in the English literature. ${ }^{11}$

The differentiation between a primary carcinoma arising from HSGT and a metastatic lesion from primary carcinoma of the salivary gland carries some challenges. In cases of cervical malignant salivary tumour, a careful search for a primary salivary gland cancer should be performed. ${ }^{3}$

Takeda and Suzuki ${ }^{12}$ described the criteria for diagnostic a neoplasm arising from HST into a lymph node; (tumour is a primary lesion with no sign of malignancy, tumour confined to the lymphoid tissue with no extension into the surrounding tissues, the lymphoid tissues have the essential characteristics of the lymph node with marginal sinuses and lymph follicles).

The management of cervical neoplasms arising from HSGT is varies depending on their nature; benign tumours require local excision with close follow-up, malignant tumours requires more extending procedures involved neck dissection, parotidectomy if indicated and postoperative radiation for the high-grade malignancy. ${ }^{2}$

In our case presented above, there was a high suspicion of cervical metastasis of already known melanoma, taking into account the clinical criteria of the supraclavicular mass as well as the result of the cytological analysis and the metabolic hyperactivity as showed in the PET-CT. A possible metastasis of a primary tonsil carcinoma was very unlikely since the tonsil asymmetry was in favour of the right side, the localisation of the cervical mass on the opposite side and outside the usual lymphatic drainage of the tonsils. The metabolic hyperactivity of the cervical mass as showed in the PET-CT was probably a false positive, since it is very unusual for a pleomorphic adenoma. We do believed that the presence of oncocyte cells, in the histological specimen, is very atypical for pleomorphic adenoma, but this presence could explain the metabolic hyperactivity on PET-CT of the supraclavicular mass in our case.

The important thing in our case is the localisation of the tumour in the supraclavicular region, which is very atypical for cervical tumours arising from HSGT. Clinical, cytological criteria of the supraclavicular mass and especially the positivity of PET-CT mimicking a cervical metastasis of already known melanoma in the patient.

\section{Learning points}

- Cervical neoplasms arising from heterotopic salivary gland tissue (HSGT) are most often located in the upper neck and periparotid region.

- The localisation in the lower neck, especially the supraclavicular region is very rare.

- Majority of these tumours are benign with pleomorphic adenoma to being the second most frequent after Whartin's tumour.

- Malignant cervical neoplasms arising from HSGT are very rare and requires research of primary salivary glands cancer.

- Management of benign cervical neoplasms arising from HSGT requires surgical excision and close follow-up for a reason of risk of recurrence or malignant transformation, especially for pleomorphic adenoma tumour.

Contributors BH and SB involved in reporting data. MEK contributed to data acquisition. SY involved in design and data acquisition.

Funding The authors have not declared a specific grant for this research from any funding agency in the public, commercial or not-for-profit sectors.

\section{Competing interests None declared.}

\section{Patient consent for publication Obtained.}

Provenance and peer review Not commissioned; externally peer reviewed.

Open access This is an open access article distributed in accordance with the Creative Commons Attribution Non Commercial (CC BY-NC 4.0) license, which permits others to distribute, remix, adapt, build upon this work non-commercially, and license their derivative works on different terms, provided the original work is properly cited and the use is non-commercial. See: http://creativecommons.org/ licenses/by-nc/4.0/.

\section{REFERENCES}

1 Pesavento G, Ferlito A. Benign mixed tumour of heterotopic salivery gland tissue in upper neck. J Laryngol Otol 1976;90:577-84.

2 Rodgers GK, Felder H, Yunis EJ. Pleomorphic adenoma of cervical heterotopic salivary gland tissue: case report and review of neoplasms arising in cervical heterotopic salivary gland tissue. Otolaryngol Head Neck Surg 1991;104:533-6.

3 Ferlito A, Bertino G, Rinaldo A, et al. A review of heterotopia and associated salivary gland neoplasms of the head and neck. J Laryngol Otol 1999;113:299-303.

4 Singer MI, Applebaum EL, Loy KD. Heterotopic salivary tissue in the neck. Laryngoscope 1979;89:1772-8.

5 Gudbrandsson FK, Liston SL, Maisel RA. Heterotopic salivary tissue in the neck. Otolaryngol Head and Neck Surg 1982;90:279-82.

6 Cannon DE, Szabo S, Flanary VA. Heterotopic salivary tissue. Am J Otolaryngol 2012;33:493-6.

7 Youngs LA, Scofield HH. Heterotopic salivary gland tissue in the lower neck. Arch Pathol 1967:83:550-6.

8 Jernstrom P, Prietto CA. Accessory parotid gland tissue at base of neck. Arch Pathol 1962;73:473-80

9 Himalstein MR. Changing concepts in the phylogeny and embryology of the head and neck. Ear Nose Throat J 1977;56:407-12.

10 Daniel E, McGuirt WF. Neck masses secondary to heterotopic salivary gland tissue: a 25-year experience. Am J Otolaryngol 2005;26:96-100.

11 Ismı O, Vayısoğlu Y, Arpaci RB, et al. Carcinoma ex pleomorphic adenoma originating from ectopic salivary gland in the neck region: case report. Gland Surg 2015:4:567-71.

12 Takeda Y, Suzuki A. Benign pleomorpic adenoma arising in a parotid lymph node. Virchows Arch A Pathol Anat Histol 1982:396:351-6. 
Copyright 2020 BMJ Publishing Group. All rights reserved. For permission to reuse any of this content visit https://www.bmj.com/company/products-services/rights-and-licensing/permissions/

BMJ Case Report Fellows may re-use this article for personal use and teaching without any further permission.

Become a Fellow of BMJ Case Reports today and you can:

- Submit as many cases as you like

- Enjoy fast sympathetic peer review and rapid publication of accepted articles

Access all the published articles

Re-use any of the published material for personal use and teaching without further permission

Customer Service

If you have any further queries about your subscription, please contact our customer services team on +44 (0) 2071111105 or via email at support@bmj.com.

Visit casereports.bmj.com for more articles like this and to become a Fellow 